\title{
Polar desert chronologies through quantitative measurements of
}

\section{salt accumulation}

\author{
Joseph A. Graly ${ }^{1}$, Kathy J. Licht ${ }^{1}$, Gregory K. Druschel ${ }^{1}$, and Michael R. Kaplan ${ }^{2}$ \\ ${ }^{1}$ Department of Earth Sciences, Indiana University-Purdue University Indianapolis, Indianapolis, Indiana 46202, USA \\ Lamont-Doherty Earth Observatory, Palisades, New York 10964, USA
}

\begin{abstract}
We measured salt concentration and speciation in the top horizons of moraine sediments from the Transantarctic Mountains (Antarctica) and compared the salt data to cosmogenicnuclide exposure ages on the same moraine. Because the salts are primarily of atmospheric origin, and their delivery to the sediment is constant over relevant time scales, a linear rate of accumulation is expected. When salts are measured in a consistent grain-size fraction and at a consistent position within the soil column, a linear correlation between salt concentration and exposure age is evident. This correlation is strongest for boron-containing salts $\left(R^{2}>0.99\right)$, but is also strong $\left(R^{2} \approx 0.9\right)$ for most other water-extracted salt species. The relative mobility of salts in the soil column does not correspond to species solubility (borate is highly soluble). Instead, the highly consistent behavior of boron within the soil column is best explained by the extremely low vapor pressure of boric acid at cold temperatures. The environment is sufficiently dry that mobility of salt species within the soil column is controlled by vapor phase effects. In other cold desert settings, topsoil salts, specifically boron, may be employed as a proxy for relative sediment exposure age.
\end{abstract}

\section{INTRODUCTION}

Terrestrial sediment is a direct record of the history of Antarctic glaciation and geochemical processes on the landscape. The temporal context of sediment transport and moraine formation constrains past ice-sheet size and flow patterns. The extremely arid environment that covers most of Antarctica allows for the retention within soils of a wide range of atmospherically sourced salts that would be flushed from soil by liquid water in higher-precipitation environments. If we can accurately quantify the rate of salt accumulation in hyperarid environments, salt concentrations can act as a chronometer of surface exposure age.

The progressive development of salts in Antarctic soils is well documented, but has typically been assessed through qualitative descriptions of salt stages (Ugolini and Bockheim, 2008). Where the total salt content of a soil profile has been measured, a linear correlation between salt content and age emerges (Bockheim, 1997). Except in near-coastal regions, where rainfall allows for leaching of salts, soil age has been identified as the primary factor controlling salt content in the McMurdo Dry Valleys (Toner et al., 2013). Here, we present a systematic attempt to identify salt accumulation tracers whose behavior is sufficiently uniform that they can be employed as reliable geochronometers in a setting without recorded seasonal melt. We also employ a simple modeling approach to help explain why a salt-accumulation chronometer works in this setting.
Currently, cosmogenic-nuclide exposure ages are most widely employed to assess Antarctic terrestrial chronologies. However, the cost and labor involved in cosmogenic isotope measurements can make it impractical to employ the approach on a large number of samples. Antarctic exposure ages can sometimes be heterogeneous, with adjacent rocks in moraines and sedimentary sequences displaying widely varying ages (e.g., Brook et al., 1995; Bromley et al., 2010). A complementary approach using salt concentrations may therefore expand the applications of surface exposure dating in Antarctica and help resolve heterogenous cosmogenic-nuclide data sets. While salt chronometers are unlikely to replace cosmogenic dating, we make a case that they can provide a parallel and technically simpler approach across a range of Antarctic cold desert settings.

\section{BACKGROUND}

The dominant salt species in most Antarctic soils are sulfates, chlorides, and nitrates (Bockheim, 1997), though trace halides $(\mathrm{F}, \mathrm{Br})$ and borate are also considered. In the McMurdo Dry Valleys, atmospheric sources of sulfate dominate inland, and sea spray dominates near the coast, though in both settings a non-negligible terrestrial weathering component is also inferred (Bao and Marchant, 2006). Chloride also shows diminishing influence of sea spray with distance inland (Bao et al., 2008). Nitrates have isotopic signatures consistent with an exclusively atmospheric origin (Michalski et al., 2005). Boron isotopes suggest a primarily atmospheric origin, with some trace mineral boron (Leslie et al., 2014). However, the Dry Valleys boron isotope values that suggest a trace mineral component could also form from Rayleigh distillation during the precipitation of atmospheric boron (Rose-Koga et al., 2006).

Atmospheric aerosols exist either as acid vapors and gases (e.g., $\mathrm{HNO}_{3}, \mathrm{~N}_{2} \mathrm{O}_{5}$, etc.) or as anion-cation pairs, commonly adhering to particulate matter. Upon deposition through a range of dry and precipitation-driven processes, acidic aerosols will encounter earth materials and react to form salts. Though halides (i.e., chloride) source primarily from sea spray aerosols, atmospheric pathways exist by which they are oxidized and incorporated into acidic aerosol gases (Andreae and Crutzen, 1997). While atmospheric boron exists mostly as a vapor of boric acid, this vapor is not stable at low temperatures. At ground surface temperatures $<-25^{\circ} \mathrm{C}$ (as commonly prevail in Antarctica), boric acid vapors adhere to atmospheric particles and are deposited in the particulate fraction (Anderson et al., 1994).

In ice cores reflective of contemporary climate at Vostok Station (1000 km inland), sea salts make up 36\% of aerosol deposition (Legrand and Mayewski, 1997). During glacial periods, which have higher winds, salt flux increases to $54 \%$ of total deposition; nitrate flux increases likewise. In contrast, ice core records show atmosphere-sourced (non-sea salt) sulfate deposition has relatively little variation between the Holocene and Pleistocene periods (e.g., Iizuka et al., 2012). Acid flux is similarly constant in the Vostok core, with $\sim 2 \mu \mathrm{eq} \mathrm{L}^{-1}$ of $\mathrm{H}^{+}$deposition (Legrand and Mayewski, 1997). Studies of borate in glacial ice are presently absent.

\section{FIELD SITES AND METHODS}

Our field site is Mount Achernar moraine, located in the central Transantarctic Mountains $\left(84.2^{\circ} \mathrm{S}, 161^{\circ} \mathrm{E}\right), \sim 1800 \mathrm{~m}$ above sea level and $\sim 750 \mathrm{~km}$ from seasonally open ocean water. Sediment emerges onto the moraine via sublimation of Law Glacier-an outlet that flows off of the polar plateau ( $20 \mathrm{~km}$ inland) toward the Ross Ice Shelf ( 100 km downstream). Progressively greater sediment thicknesses are 
found with distance from the active ice margin; these accumulations rest above stagnant glacial ice (Bader et al., 2017; Scarrow et al., 2014). Moraine sediment also emerges from much smaller, secondary ice bodies that flow over the mountains flanking the moraine: Lewis Cliff Ice Tongue and a few small, unnamed ice tongues. Though Lewis Cliff Ice Tongue is the site of evaporative features associated with discharging subglacial waters (Fitzpatrick et al., 1990), the rest of the moraine does not have evaporite features, and soil salts found at Mount Achernar are comparable to those elsewhere in Antarctica. Unlike in the McMurdo Dry Valleys, summer temperatures do not reach $0{ }^{\circ} \mathrm{C}$ at Mount Achernar moraine, melt is restricted to very low-albedo surfaces, fallen snow is lost to sublimation, and ground ice is not observed (Scarrow et al., 2014). This absence of abovefreezing temperatures differs importantly from sites of previous studies on the transport of salts to depth in polar settings (e.g., Amundson et al., 2012; Hagedorn et al., 2010).

We collected 38 sediment samples from a single transect running from the margin of Law Glacier to the back of the moraine (Fig. 1). Sediment was collected with an inert plastic scoop and stored in plastic bags. In general, samples were collected from broad moraine crest ridges within $2-5 \mathrm{~cm}$ of the surface, just below the assumed depth of wind deflation. Soils here lack distinct salt crusts or pans, and most are distinctly oxidized (Bader et al., 2017). In a few cases, additional samples were collected at depth within a soil pit, directly below a distinct oxidation horizon. To interpret the patterns of

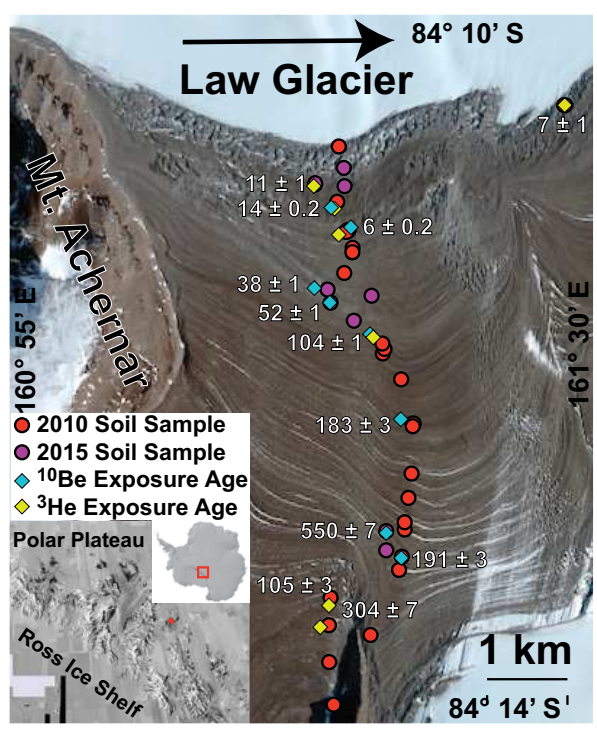

Figure 1. Sample location map (Transantarctic Mountains, Antarctica) showing corresponding cosmogenic-nuclide exposure ages (in ka) (Kaplan et al., 2017). ${ }^{10} \mathrm{Be}$ age shown unless only ${ }^{3} \mathrm{He}$ is available at location. Digital Globe imagery (@2014) provided by the Polar Geospatial Center (St. Paul, Minnesota, USA). salts with depth in both these pits and others sampled by Scarrow et al. (2014), we modeled the solubility of the principal salts at measured ratios and freezing-point temperatures. The model was implemented with Geochemist's Workbench software (see details in the GSA Data Repository ${ }^{1}$ ).

The soil samples were collected along the same transect where boulder samples had been previously analyzed for cosmogenic isotope abundance (Kaplan et al., 2017). Eleven of the cosmogenic isotope samples were located within $100 \mathrm{~m}$ of soil samples collected along the same ridge crest, allowing for direct comparison between ${ }^{10} \mathrm{Be}-{ }^{26} \mathrm{Al}-{ }^{3} \mathrm{He}$ ages and the chemical properties of surrounding soil (Fig. 1). The cosmogenic nuclide exposure ages generally increase with distance from the margin. However, some secondary discrepancies in the relationship between distance and age are observed, as discussed below.

Sediment samples were freeze-dried and dry sieved. In order to standardize approximately for grain-size variation, analyses were performed on only the $<63 \mu \mathrm{m}$ fraction (where salts occur in greatest abundance). One gram of dry sample was weighed into a sterile Falcon tube, and 40 $\mathrm{ml}$ of Milli-Q water was subsequently added. Each sample was agitated until all sediment was in suspension, and placed on a vibrating table that maintained suspension for $120 \mathrm{~min}$. Samples were then centrifuged for $20 \mathrm{~min}$ at 3300 rotations $\mathrm{min}^{-1}$. The supernatant water was then decanted for analysis. The dissolved component of the samples was analyzed for $\mathrm{Na}, \mathrm{K}$, $\mathrm{Ca}, \mathrm{Mg}, \mathrm{S}$, and B on a Perkin-Elmer Optima 7000 inductively coupled plasma-optical emission spectrometer (ICP-OES) and for $\mathrm{Cl}^{-}, \mathrm{SO}_{4}^{2-}$, $\mathrm{NO}_{3}^{-}, \mathrm{NO}_{2}{ }^{2-}, \mathrm{Fl}^{-}, \mathrm{PO}_{4}^{3-}$, and $\mathrm{Br}^{-}$on a Thermo 2 ion chromatograph.

\section{RESULTS}

Total dissolved solids in the water extraction range from 20 to $2000 \mu \mathrm{mol}$ salt per gram sediment (Table DR1 in the Data Repository). Near-zero-ionic-strength samples are found closest to the active ice, where sediment is freshly emerging, and the concentrations of all detectable ions increase exponentially with distance from the ice margin (Fig. 2). In most samples, $\mathrm{SO}_{4}^{2-}$ is the most abundant anion. $\mathrm{Cl}^{-}$is more abundant in low-ionic-strength samples freshly emerging from ice and in the two highest-ionic strength samples. Either $\mathrm{Na}$ or $\mathrm{Ca}$ is the most abundant cation, with

${ }^{1}$ GSA Data Repository item 2018105, Appendix DR1 (chemical results), Appendix DR2 (comparison of upper and lower sections of soil profiles along with geochemical modeling), and Appendix DR3 (comparison of estimated aerosol fallout rates to aerosol flux in Antarctic ice cores), is available online at http://www geosociety.org/datarepository/2018/ or on request from editing@geosociety.org. higher-ionic-strength samples tending to have greater $\mathrm{Na}$ relative to $\mathrm{Ca}$.

The largest deviation from the distance-salt content correlation occurs between 4200 and $5500 \mathrm{~m}$ from the ice margin, where ionic concentrations consistently fall and then rise over several samples. This region is near where surface morphology suggests a complex boundary between sediment supplied laterally from Law Glacier and sediment supplied terminally from Lewis Cliff Ice Tongue. A smaller but significant deviation also occurs between 250 and 500 $\mathrm{m}$ from the ice margin, where ionic concentrations are elevated compared to the surrounding regions. This corresponds to a region where the parallel-ridge topography of the region gives way to a 500-m-wide flat-lying zone. The soils in this zone are more lightly colored than in surrounding areas, suggesting greater oxidation.

Highly significant, linear correlations are found between the concentrations of all detectable ions and the cosmogenic-nuclide exposure age on boulders from the same moraine crest (Fig. 2). Both ionic concentrations and cosmogenic-nuclide exposure ages show the same two major deviations with distance from Law Glacier: specifically, the drop in concentrations $\sim 5 \mathrm{~km}$ corresponds to a fall and then rise in exposure age of $\sim 400 \mathrm{k} . \mathrm{y}$., and the rise between 250 and $500 \mathrm{~m}$ corresponds to a region where ca. 14 ka boulders are found closer to Law Glacier than ca. 6 ka boulders.

This correlation between salt concentration and moraine age is strongest for boron $\left(\mathrm{R}^{2}>0.99\right)$. Boron concentrations also consistently increase or decrease in samples located between two cosmogenic-nuclide measurements (Fig. 2). Most ions are more heterogeneous than boron, varying considerably in their relative abundance between exposure-age samples. Such heterogeneity is particularly pronounced in the higher-ionic-strength samples (Fig. 2). Even with this variability, the $\mathrm{R}^{2}$ value is near 0.9 for most major ions, and for all ions considered together.

In samples where sediment was sampled above and below an oxidative weathering horizon, the ionic strength of the extracted salts decreases by a factor of three across the boundary (Table DR2). This decrease is caused by a factor-of-five to order-of-magnitude drop in sulfate and boron concentrations, whereas chloride and nitrate concentration are approximately constant over the boundary. Contrastingly, our Geochemist's Workbench model shows high solubility for borate and chlorite, and minimal solubility for nitrate and sulfate in conditions relevant to these soil pits (Fig. DR2). At sites where sediment was collected from adjoining ridges and troughs, anion concentrations were much larger in the ridges for boron and sulfate and mostly comparable between ridges and troughs for chloride and nitrate (Table DR2). 

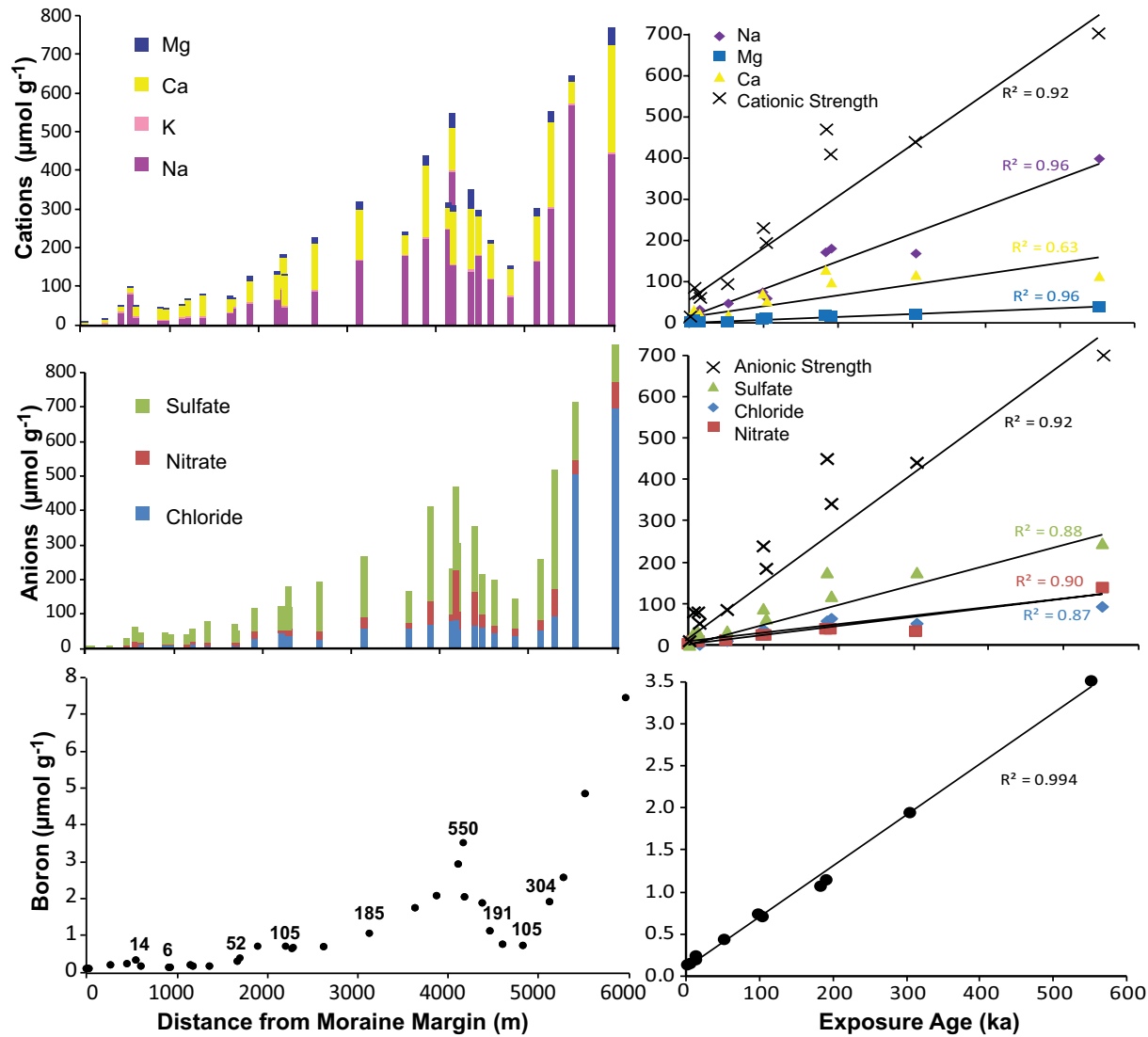

Figure 2. Left: Change in concentration per gram soil of cations, anions, and borate with distance from moraine margin. Errors are within symbol size. Numbers in boron plot reflect cosmogenic-nuclide exposure ages (in ka). Right: Correlation between ion concentration and age for 11 samples where adjoining cosmogenic-nuclide exposure age exists.

\section{DISCUSSION}

The strong correspondence between boron concentrations measured in the top $5 \mathrm{~cm}$ of the soil and cosmogenic-nuclide exposure age suggests that borate is sufficiently immobile in the soil column of sediments in interior Antarctica that little, if any, is transported to depth. This is in strong contrast with our solubility model results, which show borate to be substantially more soluble than nitrate or sulfate (Fig. DR2). This suggests that flow through porous media has a minimal effect on the downward mobility of salts in this setting. Relative acid strength also has little explanatory power: sulfate and borate form from strong acids and weak acids respectively, and both remain largely in the top few centimeters of soil. We propose that boron immobility is best explained by the extremely low vapor pressures for boric acid at temperatures prevalent near the Antarctic polar plateau. Boric acid vapor pressures are on the order of $10^{-10} \mathrm{~Pa}$ at temperatures ranging from $-25^{\circ} \mathrm{C}$ to $-20{ }^{\circ} \mathrm{C}$ (Pankajavalli et al., 2007). Vapor pressure differences also explain the relative mobility of sulfate, chloride, and nitrate salts. At these temperatures, sulfuric acid vapor pressures are on the order of $10^{-6} \mathrm{~Pa}$ (Gmitro and Vermeulen, 1964), nitric acid pressures are on the order of $1 \mathrm{~Pa}$ (Hanson and Mauersberger, 1988), and hydrochloric acid pressures are on the order of $10^{3} \mathrm{~Pa}$ (Fritz and Fuget, 1956). Correspondingly, chloride has the highest relative abundances in lower portions of the soil profile, followed by nitrate, and minimal amounts of borate and sulfate are found below oxidative weathering horizons (Table DR2). Under this model, occasional snow accumulation events would provide a vapor gradient in the top of the soil column as the snow sublimates and allow the vapors of acidic aerosols to move the depth. The multiple-orders-of-magnitude differences in the vapor pressures would allow for acid aerosol deposition to mobilize chloride and nitrate anions, but not sulfate or borate anions.

All ions have strong correlations with exposure age, though the boron correlation is the most robust (Fig. 2). Note that in the youngest soils ( $<20 \mathrm{ka})$, the boron correlation is near the lower limit of detection and might not be helpful for resolving age discrepancies within younger time periods. Apart from the boron data, the ion data tend to scatter above the linear trendline in younger soils and below the trendline in older soils. Excepting boron, sulfate, and magnesium, the data could be represented equally well or better with a logarithmic or power-law trend. Inasmuch as existing salts limit further salt accumulation or promote increased transport of salts to depth, nonlinear accumulation of salts within the top of the soil column may be expected. Because much of the atmospheric aerosol flux is acidic, cation contributions to salts can vary with the mineral species present in the soil as well as saturation effects in certain reactions (Salvatore et al., 2013); such effects may be limiting the accumulation of calcium in the older soils.

Because sulfate is not appreciably transported to depth in this setting, we can estimate its flux at $\sim 10-15 \mu$ eq $\mathrm{m}^{-2} \mathrm{yr}^{-1}$ (see analysis in the Data Repository). While this is approximately a factor of two lower than sulfate fluxes found in ice cores on the polar plateau, it closely matches data from the Dominion Range ice core, $\sim 100 \mathrm{~km}$ away, which preserves sulfate fallout of $10.5 \pm 1.9 \mu \mathrm{mol} \mathrm{m}^{-2} \mathrm{yr}^{-1}$ for the Holocene and $\sim 17 \mu \mathrm{mol} \mathrm{m} \mathrm{mr}^{-2}$ for the last glacial maximum (Mayewski et al., 1990). The match between sulfate flux to sediment and sulfate flux to nearby ice suggests that the water-extractable anions present in Mount Achernar moraine derive primarily from atmospheric aerosols, consistent with data collected elsewhere on the continent (e.g., Michalski et al., 2005).

Lyons et al. (2016) performed a similar analysis comparing nitrate concentrations along the Beardmore Glacier to flux from the Dominion Range ice core. They interpreted their data as a "wetting age" that dated the last major melt events at their sites. Our analysis suggests that boron may be preferable to nitrate for wettingage analyses, because it is less mobile under dry conditions and more soluble under wet ones. If the boron measurements at Mount Achernar are interpreted as a wetting age, major melt has not occurred at the site for $\sim 10^{6} \mathrm{yr}$ (Fig. 2).

The key finding from this study is that the data from Mount Achernar moraine strongly support the use of borate concentrations or other salt concentrations as an age proxy in Antarctic cold desert environments. Where the long-term flux of the relevant salts is known from nearby ice cores in sufficiently similar environments and where the change in salt concentration with depth is known, this method might be used as an absolute chronometer. Where these conditions do not apply, measurements of salt or borate can be used in settings where the age is calibrated by another method (such as cosmogenic-nuclide exposure dating). The method may be subject to some of the same geomorphic limitations as cosmogenic isotope dating. If the soil strata are physically mixed or overturned, the age relationship will no longer apply. However, it is unlikely that any borate (or other salt) would be inherited from the subglacial environment, as is evidenced by the near-zero salt concentrations in samples taken from the margin of Law Glacier. 


\section{CONCLUSIONS}

The water-soluble content of the top layer of soil in Antarctic glacial sediment appears to be highly predictive of exposure age when a single fine-grain-size aliquot is analyzed. Comparisons to cosmogenic isotope data from rocks collected adjacent to the soil show highly significant correlations between ionic strength of various salts and cosmogenic-nuclide exposure age. The strongest correlation $\left(\mathrm{R}^{2}>0.99\right)$ is with borate, likely due to extremely low vapor pressures for boric acid under very cold temperature conditions. The correlation with total ionic strength and other individual ions is also highly predictive $\left(\mathrm{R}^{2}>0.9\right)$. Measurements of borate or total salt content could be used as an inexpensive and reliable chronometer in cold, arid environments, especially in conjunction with exposure age measurements that can calibrate the local concentration-age relationship.

\section{ACKNOWLEDGMENTS}

This work would not have been possible without support from National Science Foundation Office of Polar Programs grants 1443433, 1043572, and 0944475; an Indiana University Collaborative Research Grant; and logistical assistance from the Antarctic Support Contract. The 2010 and 2015 field crews, particularly N. Bader, assisted in sample collection. S. Cox assisted with laboratory work. G. Filippelli and J. Mosley assisted with technical aspects of sample analysis. Reviews by D.J. Morgan, B. Lyons, and G. Balco, along with editing by M. Quigley and J. Spotila, greatly improved the manuscript.

\section{REFERENCES CITED}

Amundson, R., Barnes, J.D., Ewing, S., Heimsath, A., and Chong, G., 2012, The stable isotope composition of halite and sulfate of hyperarid soils and its relation to aqueous transport: Geochimica et Cosmochimica Acta, v. 99, p. 271-286, https:// doi.org/10.1016/j.gca.2012.04.044.

Anderson, D.L., Kitto, M.E., McCarthy, L., and Zoller, W.H., 1994, Source and atmospheric distribution of particulate and gas-phase boron: Atmospheric Environment, v. 28, p. 1401-1410, https://doi.org /10.1016/1352-2310(94)90203-8.

Andreae, M.O., and Crutzen, P.J., 1997, Atmospheric aerosols: Biogeochemical sources and role of atmospheric chemistry: Science, v. 276, p. 1052-1058, https://doi.org/10.1126/science.276.5315.1052.

Bader, N.A., Licht, K.J., Kaplan, M.R., Kassab, C., and Winckler, G., 2017, East Antarctic ice sheet stability recorded in a high-elevation ice-cored moraine: Quaternary Science Reviews, v. 159, p. 88-102, https://doi.org/10.1016/j.quascirev.2016.12.005.

Bao, H., and Marchant, D.R., 2006, Quantifying sulfate components and their variations in soils of the McMurdo Dry Valleys, Antarctica: Journal of Geophysical Research, v. 111, D16301, https:// doi.org/10.1029/2005JD006669.
Bao, H., Barnes, J.D., Sharp, Z.D., and Marchant, D.R., 2008, Two chloride sources in soils of the McMurdo Dry Valleys, Antarctica: Journal of Geophysical Research, v. 113, D03301, https:// doi.org/10.1029/2007JD008703.

Bockheim, J.G., 1997, Properties and classification of cold desert soils from Antarctica: Soil Science Society of America Journal, v. 61, p. 224-231, https://doi.org/10.2136/sssaj1997 $.03615995006100010031 x$.

Bromley, G.R.M., Hall, B.L., Stone, J.O., Conway, H., and Todd, C.E., 2010, Late Cenozoic deposits at Reedy Glacier, Transantarctic Mountains: Implications for former thickness of the West Antarctic Ice Sheet: Quaternary Science Reviews, v. 29, p. 384-398, https://doi.org/10.1016/j.quascirev 2009.07.001.

Brook, E.J., Kurz, M.D., Ackert, R.P., Raisbeck, G., and Yiou, F., 1995, Cosmogenic nuclide exposure ages and glacial history of late Quaternary Ross Sea drift in McMurdo Sound, Antarctica: Earth and Planetary Science Letters, v. 131, p. 41-56, https://doi.org/10.1016/0012-821X(95)00006-X.

Fitzpatrick, J.J., Muhs, D.R., and Jull, A.J.T., 1990, Saline minerals in the Lewis Cliff Ice Tongue, Buckley Island quadrangle, Antarctica, in Bentley, C.R., ed., Contributions to Antarctic Research I: American Geophysical Union Antarctic Research Series 50, p. 57-69, https://doi.org/10.1029 /AR050p0057.

Fritz, J., and Fuget, C., 1956, Vapor pressure of aqueous hydrogen chloride solutions, $0^{\circ}$ to $50^{\circ} \mathrm{C}$ : Industrial and Engineering Chemistry Chemical and Engineering Data Series, v. 1, p. 10-12, https://doi.org/10.1021/i460001a002.

Gmitro, J.I., and Vermeulen, T., 1964, Vapor-liquid equilibria for aqueous sulfuric acid: American Institute of Chemical Engineers Journal., v. 10, p. 740-746, https://doi.org/10.1002/aic.690100531.

Hagedorn, B., Sletten, R.S., Hallet, B., McTigue, D.F., and Steig, E.J., 2010, Ground ice recharge via brine transport in frozen soils of Victoria Valley, Antarctica: Insights from modeling $\delta^{18} \mathrm{O}$ and $\delta$ D profiles: Geochimica et Cosmochimica Acta, v. 74, p. 435-448, https://doi.org/10.1016/j.gca 2009.10.021.

Hanson, D., and Mauersberger, K., 1988, Vapor pressures of $\mathrm{HNO}_{3} / \mathrm{H}_{2} \mathrm{O}$ solutions at low temperatures: Journal of Physical Chemistry, v. 92, p. 61676170, https://doi.org/10.1021/j100332a063.

Iizuka, Y., Uemura, R., Motoyama, H., Suzuki, T., Miyake, T., Hirabayashi, M., and Hondoh, T., 2012, Sulphate-climate coupling over the past 300,000 years in inland Antarctica: Nature, v. 490, p. 81-84, https://doi.org/10.1038/nature11359.

Kaplan, M.R., Licht, K.J., Winckler, G., Schaefer, J.M., Bader, N., Mathieson, C., Roberts, M., Kassab, C.M., Schwartz, R., and Graly, J.A., 2017, Middle to Late Pleistocene stability of the central East Antarctic Ice Sheet at the head of Law Glacier: Geology, v. 45, p. 967-970, https://doi.org /10.1130/G39189.1.

Legrand, M., and Mayewski, P., 1997, Glaciochemistry of polar ice cores: A review: Reviews of Geophysics, v. 35, p. 219-243, https://doi.org/10 .1029/96RG03527.
Leslie, D., Lyons, W.B., Warner, N., Vengosh, A., Olesik, J., Welch, K., and Deuerling, K., 2014, Boron isotopic geochemistry of the McMurdo Dry Valley lakes, Antarctica: Chemical Geology, v. 386, p. 152-164, https://doi.org/10.1016/j.chemgeo 2014.08.016.

Lyons, W.B., Deuerling, K., Welch, K.A., Welch, S.A., Michalski, G., Walters, W.W., Nielsen, U., Wall, D.H., Hogg, I., and Adams, B.J., 2016, The soil geochemistry in the Beardmore Glacier region, Antarctica: Implications for terrestrial ecosystem history: Scientific Reports, v. 6, 26189, https:// doi.org/10.1038/srep26189.

Mayewski, P.A., Twickler, M.S., Lyons, W.B., and Spencer, M.J., 1990, The Dominion Range ice core, Queen Maud Mountains, Antarctica-General site and core characteristics with implications: Journal of Glaciology, v. 36, p. 11-16, https://doi.org/10.3189/S0022143000005499.

Michalski, G., Bockheim, J.G., Kendall, C., and Thiemens, M., 2005, Isotopic composition of Antarctic Dry Valley nitrate: Implications for $\mathrm{NO}_{\mathrm{y}}$ sources and cycling in Antarctica: Geophysical Research Letters, v. 32, L13817, https://doi.org /10.1029/2004GL022121.

Pankajavalli, R., Anthonysamy, S., Ananthasivan, K., and Vasudeva Rao, P.R., 2007, Vapour pressure and standard enthalpy of sublimation of $\mathrm{H}_{3} \mathrm{BO}_{3}$ : Journal of Nuclear Materials, v. 362, p. 128-131, https://doi.org/10.1016/j.jnucmat.2006.12.025.

Rose-Koga, E.F., Sheppard, S.M.F., Chaussidon, M., and Carignan, J., 2006, Boron isotopic composition of atmospheric precipitations and liquidvapour fractionations: Geochimica et Cosmochimica Acta, v. 70, p. 1603-1615, https://doi.org /10.1016/j.gca.2006.01.003.

Salvatore, M.R., Mustard, J.F., Head, J.W., Cooper, R.F., Marchant, D.R., and Wyatt, M.B., 2013, Development of alteration rinds by oxidative weathering processes in Beacon Valley, Antarctica, and implications for Mars: Geochimica et Cosmochimica Acta, v. 115, p. 137-161, https:// doi.org/10.1016/j.gca.2013.04.002.

Scarrow, J.W., Balks, M.R., and Almond, P.C., 2014, Three soil chronosequences in recessional glacial deposits near the polar plateau, in the Central Transantarctic Mountains, Antarctica: Antarctic Science, v. 26, p. 573-583, https://doi.org /10.1017/S0954102014000078.

Toner, J.D., Sletten, R.S., and Prentice, M.L., 2013, Soluble salt accumulations in Taylor Valley, Antarctica: Implications for paleolakes and Ross Sea Ice Sheet dynamics: Journal of Geophysical Research: Earth Surface, v. 118, p. 198-215, https:// doi.org/10.1029/2012JF002467.

Ugolini, F.C., and Bockheim, J.G., 2008, Antarctic soils and soil formation in a changing environment: A review: Geoderma, v. 144, p. 1-8, https:// doi.org/10.1016/j.geoderma.2007.10.005.

Manuscript received 23 August 2017

Revised manuscript received 22 January 2018

Manuscript accepted 24 January 2018

Printed in USA 